IZA DP No. 9371

The Effects of State Merit Aid Programs on Attendance at Elite Colleges

David L. Sjoquist

John V. Winters

September 2015 


\title{
The Effects of State Merit Aid Programs on Attendance at Elite Colleges
}

\author{
David L. Sjoquist \\ Georgia State University
}

John V. Winters

Oklahoma State University

and IZA

\section{Discussion Paper No. 9371 \\ September 2015}

\author{
IZA \\ P.O. Box 7240 \\ 53072 Bonn \\ Germany \\ Phone: +49-228-3894-0 \\ Fax: +49-228-3894-180 \\ E-mail: iza@iza.org
}

\begin{abstract}
Any opinions expressed here are those of the author(s) and not those of IZA. Research published in this series may include views on policy, but the institute itself takes no institutional policy positions. The IZA research network is committed to the IZA Guiding Principles of Research Integrity.

The Institute for the Study of Labor (IZA) in Bonn is a local and virtual international research center and a place of communication between science, politics and business. IZA is an independent nonprofit organization supported by Deutsche Post Foundation. The center is associated with the University of Bonn and offers a stimulating research environment through its international network, workshops and conferences, data service, project support, research visits and doctoral program. IZA engages in (i) original and internationally competitive research in all fields of labor economics, (ii) development of policy concepts, and (iii) dissemination of research results and concepts to the interested public.
\end{abstract}

IZA Discussion Papers often represent preliminary work and are circulated to encourage discussion. Citation of such a paper should account for its provisional character. A revised version may be available directly from the author. 
IZA Discussion Paper No. 9371

September 2015

\section{ABSTRACT \\ The Effects of State Merit Aid Programs on Attendance at Elite Colleges*}

State merit aid programs have been found to reduce the likelihood that students attend college out-of-state. Using the U.S. News \& World Report rankings of colleges and universities to measure college quality and Integrated Postsecondary Education Data System data to measure enrollment, we explore how this reduction in out-of-state enrollment differs by the academic quality of the institution. Our results suggest that state merit aid programs do not reduce the likelihood that a student attends a top ranked school, but that these programs do reduce the likelihood of enrolling at less prestigious out-of-state schools, with generally larger effects the lower the ranking of the schools.

JEL Classification: H31, I22, J24

Keywords: merit aid, college choice, college quality, elite colleges

Corresponding author:

John V. Winters

Oklahoma State University

331 Business Building

Stillwater, OK 74078-4011

USA

E-mail: jvwinte@okstate.edu

\footnotetext{
* The authors thank Rajashri Chakrabarti and Joydeep Roy for helpful comments. All errors, omissions, or opinions are solely the responsibility of the authors.
} 


\section{Introduction}

Over the past 10 years a substantial number of papers have been published that explore the various effects of state funded student merit aid programs. ${ }^{1}$ One of the early findings of this research is that merit aid reduces the probability that a student goes to college out-of-state. A question of interest and policy relevance is where these students would have gone to college in the absence of the merit aid program. A related stream of research has examined the determinants of college enrollment choices more generally, with enrollment at elite institutions receiving special attention, likely because, as we discuss below, of the considerable benefits to a student from attending an elite school and the important societal role that elite institutions play in educating some of the nation's greatest young minds. In this paper, we examine the effects of state merit-based student financial aid programs on out-of-state enrollment, looking separately at different sets of colleges and universities that vary in their level of prestige. Specifically, we consider whether out-of-state enrollment at elite institutions responds differently to state merit aid programs than enrollment at less prestigious schools. Despite the importance of this issue, it has received very little attention in previous research, and thus our research fills an important gap in the research literature. We also contribute to the broader literature on college choice.

There are a few articles that provide estimates of the number of students who go to college in-state rather than out-of-state due to merit aid; see Dynarski (2000), Cornwell et al. (2006), Zhang and Ness (2010), and Orsuwan and Heck (2009). ${ }^{2}$ Knowing where students would

\footnotetext{
${ }^{1}$ Dynarski (2004) provides a discussion of how state-funded merit aid programs work. In general, merit aid is restricted to in-state students with a B or better GPA. The size of the aid ranges across states from a few hundred dollars to full tuition.

2 Dynarski (2000) conducted one of the first studies of the implications of student merit aid programs on enrollment profiles, focusing on Georgia's HOPE Scholarship program. To provide some notion of the size of the effect of HOPE on out-of-state enrollment, she considers two- and four-year colleges in states that border Georgia, and finds that in 1992 (pre-HOPE) 5,000 Georgian freshmen attended college in those states, while in 1998 (post-HOPE) that number had fallen to 4,500. Cornwell et al. (2006) consider the same issue and find that Georgia's HOPE

Scholarship program reduced the number of Georgians that go to an out-of-state four-year school by 560 . Zhang and
} 
have gone without merit aid is of considerable importance but much less explored. Goodman (2008) finds that the Massachusetts' Adams Scholarship merit aid program induced six percent of eligible students to switch from four-year private colleges to four-year public colleges. Goodman also explores heterogeneous effects by standardized test score percentiles and finds that the effect of merit aid on in-state public enrollment diminishes as ability increases and is statistically insignificant for students above the $90^{\text {th }}$ percentile. Cohodes and Goodman (2014) further examine the effect of the Adams Scholarship on college switching and find that roughly half of such switches were to lower quality schools and that this reduction in college quality harmed students. However, Chakrabarti and Roy (2013) examine effects of Georgia's HOPE Scholarship and find that HOPE made students from Georgia overall more likely to attend more selective colleges. ${ }^{3}$

Of course, there are important differences between Massachusetts and Georgia and their merit aid programs. Georgia's HOPE Scholarship is a large program that until recently covered full tuition and fees at in-state institutions and was awarded very broadly; for example, in 19951996 HOPE was awarded to 70 percent of incoming freshmen at Georgia public colleges and universities (Sjoquist and Winters 2013). Massachusetts’ Adams Scholarship covers in-state tuition but not fees which are more substantial than tuition at Massachusetts public colleges and

Ness (2010) use IPEDS data to estimate the effect of student merit aid on college enrollment in 10 states. In particular, they estimate that merit aid programs reduced out-of-state enrollment by nearly 9 percent, but with substantial differences across states. Orsuwan and Heck (2009) also use IPEDS data and consider the effect on student out-migration for all states that adopted merit aid programs. They find that the percentage of students going to college out-of-state was increasing prior to the adoption of merit aid but began to decline upon the adoption of merit aid; they do not provide any summary measure of the percentage change in the number of students going to college out-of-state. Other studies examining the effects of merit aid on in-state/out-of-state college enrollment include Binder and Ganderton (2004), Farrell and Kienzl (2009), and Hawley and Rork (2013).

${ }^{3}$ Their overall estimates include students switching from one in-state college to another and from out-of-state colleges to in-state colleges. However, their focus is to examine separate effects on in-state and out-of-state college enrollment. They find that Georgia resident freshmen enrolling in-state attended more selective schools post-HOPE and Georgia freshmen enrolling out-of-state also attended more selective schools post-HOPE. 
universities; the Adams Scholarship is also much more selectively targeted to a narrower group of high ability students. Finally, the public and private higher education options and pre-merit program enrollment patterns in the two states differ, with Massachusetts having a higher percentage of students enrolled at private colleges and universities, both in-state and out-of-state.

For many state merit aid programs, keeping the state's "best and brightest" high school graduates in-state for college is an important goal. Thus, it is of interest to know if a merit aid program attracts the very best of the state's students to stay in-state or those who just marginally quality for merit aid. With the exception of Goodman (2008), Cohodes and Goodman (2014), and Chakrabarti and Roy (2013) studies of the effects of merit aid on out-of-state enrollment have been unable to say much about the academic ability of the students who stay in-state for merit aid, other than that they qualify for merit aid. While it is not feasible to identify which instate students would have gone to college out-of-state in the absence of merit aid, we can consider the change due to merit aid in out-of-state enrollment by the academic quality of the college. To the extent that students' academic ability is correlated with the academic quality of the college attended, we can infer something about the academic quality of the students by measuring how the change in enrollment differs by the academic quality of the college. In particular, we consider how enrollment of a state's students in elite colleges changes as a result of the adoption of a merit aid program.

A further concern regarding the effect of merit aid on college choice is that if students shift from out-of-state colleges that are of high academic quality to in-state schools that are of lower quality, the students' future earnings could suffer. Hoekstra (2009) finds that attending the most selective state university causes earnings to be approximately 20 percent higher for white men. Brewer, Eide and Ehrenberg (1999), Eide, Brewer and Ehrenberg (1998), Hoxby (1998), 
Hoxby and Long (1999), and Long $(2008,2010)$ obtain similar results for attendance at other elite institutions, although Dale and Krueger (2002) find effects from attending a higher tuition institution but not a more selective one. Other benefits of attending an elite college have also been identified; see Hurwitz (2012) for a discussion. Furthermore, there may be societal benefits from having highly talented students educated at elite institutions and then become leaders in science, business, and government.

We investigate how out-of-state enrollment in elite and in non-elite colleges changes as a result of state merit aid programs. We use U.S. News \& World Report (USNWR) rankings of colleges and universities to measure college quality and Integrated Postsecondary Education Data System (IPEDS) data to measure enrollment at each institution by state of residence. We are especially interested in effects of merit aid on enrollment at the very top colleges and universities, which has not been explicitly considered in previous research. Our analysis also differs from Goodman (2008), Cohodes and Goodman (2014), and Chakrabarti and Roy (2013) by examining nine states with relatively large and generous merit aid programs rather than just one merit aid program. We find that merit aid significantly reduced the likelihood of enrolling at less prestigious out-of-state schools. However, our results suggest that state merit aid programs do not reduce the likelihood that a student attends a top ranked school. This is a new result in this small but important literature and has considerable implications.

The remainder of the paper proceeds as follows. In the next section we present a simple conceptual framework for our analysis. Section 3 discusses the U.S. News \& World Report college ranking, including a discussion of the studies that show that students (and which students) use USNWR rankings. Section 4 discusses our empirical approach and describes the 
data we use, while Section 5 contains the results. A summary and conclusion section completes the paper.

\section{Conceptual Framework}

The bulk of the research on college enrollment focuses on the effect of tuition and student aid on aggregate enrollment rates or on the probability that a high school graduate attends college; see Heller (1997) and Ehrenberg (2004) for reviews of the literature. Additional research addresses the choice of which college to attend, which is relevant to our analysis. Fuller, Manski and Wise (1982), building off the work of Kohn, Manski, and Mundel (1976), provide one of the earliest studies of college choice. ${ }^{4}$ Their framework, which is the standard framework for this literature, views a high school graduate as choosing from among a set of schooling and nonschooling options, where choice depends on factors such as tuition, scholarships, living expenses, the opportunity cost of schooling, college quality and student academic ability. While there are empirical studies of matriculation at specific colleges, for example Curs and Singell (2002), there are very few studies that consider student choices from among a large number of colleges. Besides Fuller, Manski, and Wise (1982), studies that explore the choice across multiple colleges were conducted by Weiler (1996) and Avery and Hoxby (2004), both of which focus on high ability students, and Long (2004), who explores how the importance of factors such as distance, tuition, and college quality have changed over time. As Nurnberg, Schapiro, and Zimmerman (2012) note, the literature is sparse; see Long (2007) for a review of this literature.

\footnotetext{
${ }^{4}$ Manski and Wise (1983) provide a more extensive discussion of college choice, but the empirical analysis is the same as Fuller, Manski and Wise (1982).
} 
The following is a simple framework, influenced by the college choice literature, in which to cast our empirical work; Jacob, McCall and Stange (2013) provide a more formal or rigorous framework. Consider a student who is choosing between two colleges, denoted by $C_{I}$ and $C_{O}$, where $C_{I}$ represents an in-state school and $C_{O}$ an out-of-state college. We assume the colleges charge different prices (i.e., tuition and other fees net of financial aid), denoted by $T_{I}$ and $T_{O}$, and differ in the set of attributes provided. These attributes include the academic quality of the college, the types of majors offered, consumption amenities such as spending on student activities, sports, and housing, the nature of the social life, etc. For the moment assume that the set of attributes can be represented by a one-dimensional variable denoted $A_{j}, j=I, O$. Assume that $T_{I}<T_{O}$ and $A_{I}<A_{O}$, in other words, the price of attributes is increasing. The student is assumed to choose the college that maximizes a preference function denoted $F\left(A_{j}, T_{j}\right)$, where $F^{l}>0$ and $F^{2}<0$.

Consider a student who, given prices and attributes, chooses $C_{O}$, the out-of-state college. Suppose now that $T_{I}$ decreases due to the availability of a new merit-based student aid program. Under what conditions will the student now prefer $C_{I}$ rather than $C_{O}$ ?

Whether $C_{I}$ now becomes the preferred school depends on the student's substitutability between $T$ and $A$, and the difference in $A_{I}$ and $A_{O}$ relative to the change in $T_{I}$. Given the substitutability, the smaller the difference between $A_{I}$ and $A_{O}$, the more likely it is that the reduction in $T_{I}$ will be sufficient for $F\left(A_{I}, T_{I}\right)$ to exceed $F\left(A_{O}, T_{O}\right)$, and thus that the student would attend college in state in the presence of the merit-based aid program. The greater the difference between $A_{I}$ and $A_{O}$, the less likely it would be that the student's preferred college would change for a given change in $T_{I}$. The greater the substitutability, the smaller the difference between $A_{I}$ and $A_{O}$ has to be in order for the student to prefer $C_{I}$ as result of the new aid program. 
There are many characteristics of a college that a student might value, but for simplicity consider two categories of characteristics, namely consumption amenities and academic quality. ${ }^{5}$ Consumption amenities include such things as ready access to ski slopes, strong athletic programs that win national titles, student activity programs, etc. Colleges differ in the extent to which they provide consumption amenities (Jacob, McCall and Stange 2013).

We assume that students differ in the relative value they place on consumption amenities and academic quality. ${ }^{6}$ This assumption is consistent with Jacob, McCall and Stange (2013), who estimate a discrete choice model in which students care about net price, academic quality, consumption amenities, proximity, and peer composition, and find significant heterogeneity of preferences across students.

Consider a student who is of high academic ability and who places a high value on academic quality relative to consumption amenities. ${ }^{7}$ Suppose that for this student $C_{O}$ is one of the relatively small number of "elite" colleges and universities that offer a very high quality academic experience. Most states do not have an elite public college or university, and most merit aid programs do not extend merit aid eligibility to students in private in-state schools (or at least not the same level of aid as for public institutions). Thus, $C_{I}$ for this student will be a college with a relatively lower academic quality. Thus, for this student we expect that the difference between $A_{I}$ and $A_{O}$ will be large, so that a small change in $T_{I}$ will be insufficient to cause the student to now prefer $C_{I}$ to $C_{O}$. Furthermore, if tuition at an elite school is high, the fact that the student chooses to attend the elite school suggests that he places great weight on quality.

\footnotetext{
${ }^{5}$ Weiler (1996) finds that non-financial characteristics of colleges are highly significant determinants of college choice, and that students weigh non-academic and academic characteristics about the same.

${ }^{6}$ Fuller, Manski and Wise (1982) find that students prefer a college with an academic quality similar to the student's academic ability.

${ }^{7}$ Long (2004) finds that for high ability students, the effect of a college's academic quality on college choice is twice as large as for other students.
} 
This is consistent with Jacob, McCall, and Stange (2013), who find that high achieving students have a greater willingness to pay for academic quality, and Long (2004); see also McDuff (2007) and Alter and Reback (2014). Thus, we do not expect that a new merit aid program would cause a student to switch from an elite out-of-state college to an in-state school.

If $C_{O}$ provides a lower academic quality, it seems reasonable to assume that there would be in-state colleges with similar academic quality. Thus for students attending a lower academic quality out-of-state school, we expect that a decrease in $T_{I}$ will be sufficient to cause at least some of these students to change their preferred school from $C_{O}$ to $C_{I}$.

Consider now students who place a relatively higher value on consumption amenities. We assume that colleges compete for such students and offer a set of consumption amenities that attract their desired student body. Jacob, McCall and Stange (2013) note that there is substantial heterogeneity across colleges in their emphasis on consumption amenities and attribute this to heterogeneity on the demand side. Given the large number of colleges, we hypothesize that the willingness to pay for $A_{O}$ over $A_{I}$ for many students is not much larger than the pre-merit difference in $T_{O}$ and $T_{I}$. Thus, we expect that a new merit aid program would cause several of the students who chose an out-of-state school because of these consumption amenities to switch from an out-of-state to an in-state college. Of course, an out-of-state college could offer a very unique consumption amenity that certain students highly desire so that a reduction in $T_{I}$ would be insufficient to cause the student's choice of college to change.

\section{U.S. News \& World Report College Rankings}

To measure the quality of colleges we use the U.S. News \& World Report ranking of colleges. As discussed below, we use the rankings released in 1990 (U.S. News \& World Report 
October 1990). As background we note that the factors used to construct the index, and thus the ranking for 1990, are:

- The selectivity of the student body as measured by: the acceptance rate; the percentage of acceptances enrolled; high school class standing; and the combined SAT or composite ACT scores.

- The degree to which the school financially supports a high-quality, full-time faculty as measured by: the ratio of full-time students to full-time faculty; the percentage of full-time faculty with doctorates; the percentage of faculty with part-time status; and average salary for tenured full professors.

- The overall financial resources as measured by total educational and general expenditures divided by total enrollment.

- Student satisfaction as measured by the percentage of 1982 to 1984 freshmen who graduated within five years.

There is a vast literature that criticizes college rankings in general and the USNWR ranking in particular; see Webster (2001) for a list of references that address these criticisms. Concern is expressed that the rankings may not measure the quality of the education obtained by students, that the factors are subject to manipulation, and that the weights for the various factors are arbitrary and that small changes in the weights can lead to significant changes in rankings. Ehrenberg (2005) discusses the many ways that colleges try to influence the ranking but that do not represent improvements in academic quality. For example, schools increasingly publicize their achievements to improve their score on academic reputation or take steps to increase the application pool so that the acceptance rates are lower. There are also reports that colleges 
misreport information; in 2012, Emory University reported that it had supplied false information to USNWR for more than a decade (Morse 2012).

The advantage of the USNWR ranking is that it combines substantial information into a single rank which proxies for the quality of the school. Despite the criticism of the factors used in the USNWR ranking, as Ehrenberg (2005) points out, most of the factors that are used in USNWR rankings are pieces of information that colleges actually include in their promotional materials. $^{8}$

USNWR changes its methodology from time to time, and colleges do change over time, so we would expect some changes in the rankings over time. While the rankings among at least the top ranked colleges do change from year to year, they do not change a lot. In 1990, USNWR ranked the top 25 national universities. Comparing the 1990 rankings to the 2015 rankings for national universities, we found that of the top 25 national universities as of 1990, 6 increased their rank by more than 5 places and 5 decreased their rank by more than 5 places (including those who fell out of the top 25), but that no school moved more than 10 places. Of the 25 schools in the 1990 rankings, 22 were in the top 25 in 2015. So, while there are changes over time, the changes from year-to-year are small.

The USNWR ranking is consistent with an alternative ranking using an entirely different methodology. Avery, Glickman, Hoxby and Metrick (2013) construct a ranking of undergraduate programs using an algorithm that relies on the choices students make among the schools to which they were accepted. We compared the top 25 universities on their list to the top 25 in the USNWR for 2004. Of the top 25 universities in the Avery et al. list, 21 are in the top 25 in the USNWR list.

\footnotetext{
${ }^{8}$ Webster (2001) conducted a principal component analysis of the USNWR rankings and concluded that the most significant ranking criterion is the average SAT score.
} 
There is evidence that the USNWR rankings are perceived as an indicator of quality. First, the USNWR issue containing college rankings is the magazine's best-selling issue and has become the "gold standard" of the college-ranking business (Ehrenberg 2005). The rankings are used in studies as a proxy for quality or reputation (see citations to relevant studies in Griffin and Rask (2007)).

Second, there are surveys that suggest that students consider college rankings in making their college choice. McDonough et al. (1998) used the Cooperative Institutional Research Program's 1995 Freshmen Survey to explore how important college "ratings in national magazines" were to the choice of college. The authors report that high-achieving students are much more likely to respond that the ratings are very important. Similarly, Machung (1998) cites the finding of a survey conducted by the Art and Science Group that found that two-thirds of parents of high-achieving, college-bound seniors felt the USNWR rankings to be "very helpful" in evaluating a college's quality; see also Chang and Osborn (2005). Clayton (2013) reviews the literature on the influence of college rankings on students' choice process and concludes that the literature supports the conclusion that rankings are more influential with students of high academic ability.

Third, there are studies that find that the rankings do in fact affect the choice of college; see Hazelkorn (2015) for a list of such studies. Monks and Ehrenberg (1999) explore the effects of changes in USNWR rankings on admission rates, acceptance rates, average SAT scores of the freshman classes, and tuition and financial aid policies. They use a set of highly ranked national universities and liberal arts colleges for the entering classes of the 1988/89 to 1998/99 academic years and prior year's fall USNWR rankings. They find that a less favorable rank leads an institution to accept a greater percentage of its applicants, that a smaller percentage of its 
admitted applicants matriculate, and the resulting entering class is of lower quality, as measured by its average SAT scores. While tuition levels are not responsive to less favorable rankings, institutions offer less visible price discounts in the form of slightly lower levels of expected selfhelp (loans and employment opportunities) and significantly more generous levels of grant aid. Monks and Ehrenberg claim that these decreases in net tuition are an attempt to attract additional students from their declining applicant pool. The Monks and Ehrenberg results were updated by Ren (2013), while Meredith (2004) and Bowman and Bastedo (2009) provide confirming results.

Griffith and Rask (2007) explore the effect of USNWR rankings on the matriculation decisions of high-ability students admitted for the fall of 1995 through 2004. They estimate, separately for students who receive financial assistance and those who don't, conditional logit models in which school choice is modeled as a function of the USNWR rank of each school along with other school and individual characteristics. For students who receive financial aid and who are considering schools in the top 20 , they find that the probability of attendance falls by about 0.15 percentage point for every 1 place difference in the college's rank, while for non-aided students the change is a 0.45 percentage point drop. These effects become smaller as the ranking of the college decreases. These effects for the USNWR rank are independent of other measures of quality (student-faculty ratio and expenditures per student), and school fixed effects. Griffith and Rask's finding suggest that colleges will be unsuccessful using merit aid to attract high-income high-ability students away from the most prestigious and highly ranked institutions, a result that is consistent with the implication of our conceptual framework.

Alter and Reback (2014) consider both rankings of academic quality (USNWR) and ranking of quality-of-life reputations (Princeton Review) using IPEDS data for the entering classes of fall 1993 through fall of 2008. Consistent with other studies, they find that the number 
of applications, the academic competitiveness of the class, and percentage of students who are out-of-state are affected in the expected direction by changes in both rankings.

\section{Empirical Approach and Data}

We consider the effects of a state's merit aid program on out-of-state enrollment among college freshmen from the state in several sets of colleges and universities grouped by USNWR categories. Our interest is to examine whether the effects of state merit aid on out-of-state enrollment differ by the "eliteness" of higher education institutions. We implement a differencein-differences regression framework, comparing elite enrollment pre- and post-adoption of merit aid and between states that did and did not adopt merit aid. The treatment group consists of cohorts who were exposed to a state merit-aid program, i.e., those who graduated from high school in a state with a merit aid program and after the program was implemented. The control group includes cohorts from states that did not adopt a merit-aid program and cohorts from merit-adopting states but who graduated high school before the merit program in their state was implemented. We estimate variants of the following regression:

$$
\ln E_{s t}=\theta \text { Merit }_{s t}+\beta X_{s t}+\Gamma_{s}+\Pi_{s t}+\varepsilon_{s t},
$$

where $\ln E_{s t}$ is the log of enrollment among recent first-time freshmen (who graduated high school in the past 12 months) from state $s$ in year $t$ in any of a set of out-of-state schools; Merit is an indicator variable equal to one if the state $s$ has a merit program in year $t$ and zero otherwise; $X$ is a set of control variables including the log of the state's population of 18 year olds, log of the state's median household income, state unemployment rate, and log of in-state tuition at the state's public flagship universities; $\Gamma_{\mathrm{s}}$ are state fixed effects; $\Pi_{s t}$ are region-by-year dummies; and $\varepsilon_{s t}$ is an error term. 
We measure $\ln E_{s t}$ using bi-annual data from the Integrated Postsecondary Education Data System (IPEDS) Residence and Migration Survey for the period 1986 through 2012. ${ }^{9}$ IPEDS reports for each college and university the number of recently graduated high school students who enroll in that college by state of residence. ${ }^{10} \mathrm{We}$ consider several alternative sets of colleges and universities as ranked by U.S. News \& World Report in their October 15, 1990 issue. We use the 1990 rankings because we do not want the rankings to be affected by the adoption of state merit aid programs, which began in the early 1990s. The 1990 USNWR rankings in total include 204 "National Universities" (universities) and 141 "National Liberal Arts Colleges" (LACs). For universities and for LACs, USNWR provides individual rankings for the top 25 , but reports only the ranking quartile for those outside the top 25 . We divide the top 25 for each group into those in the top 15 and those ranked 16-25. This gives us six ranking categories, namely, the top 15 ranked schools, the next 10 ranked schools, the rest of the top quartile, the second quartile, the third quartile, and the fourth quartile. We consider universities and LACs combined and separately, so that, for example, the top 15 universities and LACs consists of the top 15 universities plus the top 15 LACs. We also consider separate outcomes for universities and LACs. In all, this gives 18 (= 6 ranking groups $\times 3$ institution groupings) enrollment outcome variables. ${ }^{11}$ Our analysis focuses on out-of-state enrollment, so ranked

\footnotetext{
${ }^{9}$ The Residence and Migration Survey has been administered to all U.S. colleges and universities in even-numbered years since 1986 except for 1990, which is excluded. Starting in 2001, a more limited sub-sample was surveyed in odd-numbered years on a voluntary basis. However, many institutions do not respond in the odd years, so we include only the even years in our analysis.

${ }^{10}$ Prior residence data are missing for a few schools for a few years. If the observations are missing at random, it will not bias our results. The results reported in the paper rely on this assumption, although it is hard to know $a$ priori how random missing observations are. As an alternative, we imputed values for missing observations. The imputation procedure is based on a regression approach for state-institution flows that regresses observed flows (from origin states to individual institutions in non-missing years) on institution dummies and linear institution year trends, separately for merit and non-merit time periods. The regression results when we use this method are qualitatively similar to those reported in the tables in the paper.

${ }^{11}$ The 1988 flow from West Virginia to LACs ranked 16-25 was zero; the missing log value was recoded to -1. Results below are robust to excluding this observation or treating the value as zero. All other flows for the 18 primary outcomes variables were greater than zero.
} 
institutions within a state (both public and private) are excluded from our measures of that state's outflows, but see footnote 17 below. Appendix Table A reports the schools in the top quartile. Sjoquist and Winters $(2014,2015)$ identify 25 states that implemented a merit scholarship program between 1991 and 2004; six more states implemented merit programs between 2005 and 2008. However, some of these state programs are relatively small and not likely to have a sizable impact on student outcomes. Based on program characteristics including the dollar value of awards and the percentage of students receiving the merit aid, Sjoquist and Winters (2014, 2015) classify nine states as having "strong" merit aid programs; the other merit states are considered to have "weak" programs. We use their classification of strong merit aid states to measure Merit $_{s t}$. Table 1 lists the nine states and the year of adoption of their merit aid program. Weak merit aid states receive only partial treatment and should be less affected than strong merit aid states, but their partial treatment also makes them poorly suited for the control group. Weak merit states are, therefore, excluded from both the treatment and control group in our primary analysis. ${ }^{12}$

The regression analysis includes a number of control variables. State fixed effects account for time-invariant differences across states and their inclusion means that the identifying variation comes from across cohorts within states. Region-by-year dummies account for temporal differences within Census regions with minimal parametric assumptions; their inclusion means that pre- and post-merit differences in merit aid states are compared to differences in nonmerit states in the same region during the same time periods. This also means that states in other regions only affect the merit coefficient through their effects on the state control variables coefficients. Seven of the strong merit states are in the South region, while Nevada and New

\footnotetext{
${ }^{12}$ In results not shown but discussed briefly below, we did examine potential merit aid effects in weak merit states relative to non-merit states.
} 
Mexico are in the West region. South region control states include Alabama, North Carolina, Virginia, and Texas. The West region control states are Colorado and Oregon. ${ }^{13}$

The log of the state's population of 18 year olds is included to account for differences in out-flows across cohorts due to cohort size. Larger cohorts should send more people to colleges and universities both in-state and out-of-state. However, larger cohorts might disproportionately increase out-of-state enrollment if in-state institutions have constraints due to limited resources or capacity. Median household income and the unemployment rate in a state might affect both student financial capacity and student desires to leave their origin state. Higher in-state tuition at a state's flagship universities is likely to increase out-of-state enrollment among the state's residents. ${ }^{14}$ The cohort size data are obtained from the U.S. Census Bureau population estimates. Median household income is computed using the March Current Population Survey. State unemployment rates are obtained from the Bureau of Labor Statistics (BLS) Local Area Unemployment Statistics (LAUS) database. In-state tuition values are obtained from IPEDS. Flagship universities are defined as in Rizzo and Ehrenberg (2004) and Winters (2012). Specifically, the set of flagships includes all public universities classified as Research I or II in the 1994 Carnegie Foundation Classification System plus the top public institution in a few states without a Carnegie Research I or II university. The tuition variable is the mean across flagship schools in a state. Summary statistics for the main enrollment outcome variables and the state control variables are reported in Table 2, separately for strong merit states and non-merit states.

\footnotetext{
${ }^{13}$ Results below are qualitatively robust to separately 1) completely removing the Northeast and Midwest regions from the analysis; or 2) replacing region-by-year dummies with national year dummies that include all non-merit states in the control group.

${ }^{14}$ Avery and Hoxby (2004) find that the probability that a student attends a college, from among those to which the student was admitted decreases the higher the school's tuition. Long (2004) also finds that tuition negatively affects the probability of attending a particular college, but that the effect has declined over time.
} 


\section{Results}

Table 3 presents the basic results. Standard errors are clustered by origin state to account for potential serial correlation within states. ${ }^{15}$ In these regressions, we exclude states with weak merit aid programs from the analysis. In general the results are consistent with our priors. The coefficients on strong merit aid for the top 15 schools are negative but small and statistically insignificant, whether we consider just the top 15 universities, the top 15 liberal arts colleges (LACs), or the combined set. ${ }^{16}$ The results imply that the adoption of merit aid in the students' home state does not reduce the number of students attending top ranked out-of-state schools. This seems plausible, since it suggests that free tuition at in-state institutions is not a sufficient incentive for students to give up attending a top 15 school in order to attend a state public college or university. The results imply that students are price insensitive when choosing between elite and non-elite institutions, which is consistent with the literature noted above suggesting that the benefits of attending an elite institution are substantial. This finding also has implications for suggestions that merit aid programs help states retain the "best and brightest" students in-state. Strictly speaking, students capable of attending top 15 schools have the most legitimate claim to the title of "best and brightest" and their enrollment decisions appear unaltered by merit aid.

\footnotetext{
${ }^{15}$ Clustered standard errors can be biased when the number of clusters is small (Bertrand, Duflo, and Mullainathan 2004). Our main analysis includes 28 states in total, which should be sufficiently large to avoid considerable standard error bias but not enough to eliminate concerns entirely. In results not shown, we also estimated two alternative inference procedures. The first is a standard block-bootstrap that resamples entire states instead of individual state-year observations. The second is based on a related inference procedure for differences-indifferences suggested by Conley and Taber (2011) that is especially useful when there are a small number of policy changes and a large number of control groups. The inferences using both alternative procedures are very similar to using the clustered standard errors reported. No outcomes go from statistically significant with clustered standard errors to insignificant with the alternatives. One outcome (Panel C, Column 6) goes from statistically insignificant with clustered standard errors ( $\mathrm{p}$-value $=0.137$ ) to statistically significant at the ten percent level using both alternatives. The coefficients for enrollment at top 15 schools remain statistically insignificant in all three panels for both alternative inference procedures.

${ }^{16}$ Limiting this to the Top 10 in results not shown gives very similar results.
} 
All of the coefficients in Table 3 are negative. The absolute values of the coefficients on strong merit aid are larger for schools ranked below the top 15 , and are statistically significant in all but one case (Panel C Column 6). The coefficients outside the top 15 range from -0.137 to -0.369. Since the dependent variable is measured in logs, a coefficient of -0.239 (Panel A Column 2) implies that adoption of a merit aid program reduces the percentage of students going to an out-of-state college or university ranked $16^{\text {th }}$ to $25^{\text {th }}$ by roughly 23.9 percent. The effects are typically larger for universities than for LACs and tend to increase as the rank falls. The results for universities are consistent with our expectations, since we expect that the incentive provided by merit aid would have a larger effect the lower the rank of the school. The smaller effect of merit aid for LACs than for universities suggest that students have greater attachment to out-of-state LACs than out-of-state universities, i.e., merit-adopting states may have better instate substitutes for non-topped ranked national universities than for non-topped ranked national LACs. However, the size and statistical significance of the coefficients across the sets of LACs do not follow a consistent trend pattern by college rank. The lower level of significance relative to universities further suggests that the attachment to LACs is different than the attachment to universities. These results are consistent with the possibility that LACs are less homogeneous than universities so there is less substitutability among LACs, and that in choosing a college students weigh non-academic factors more heavily than students attending a university. ${ }^{17}$ Table 4 explores whether the effects differ by public and private institutions. Since almost all of the top 25 schools and most of the top quartile are private schools, we estimated the

\footnotetext{
17 The results in Table 3 include only out-of-state ranked schools. However, some students could have attended instate ranked schools and thus we estimated the model including in-state ranked private universities and colleges. The results for columns 1-4 are very similar to those in Table 3. In general, the coefficients in columns 5 and 6 become less negative and two lose their statistical significance. However, since merit aid can be used at in-state private schools, the effect of merit aid on attendance at in-state private schools is more complex, which is why we do not report these results.
} 
regressions for all schools in the 1 st quartile, as well as for the $2 \mathrm{nd}, 3 \mathrm{rd}$, and 4 th quartiles. We expect the effect of merit aid will be greater for out-of-state public institutions than for private institutions for at least two reasons. First, merit-adopting states may have better in-state substitutes for out-of-state public institutions than for private ones, similarly to what was suggested above for national universities relative to LACs. Second, merit aid will generally represent a much larger percentage change in relative tuition between the home state and out-ofstate public schools than for out-of-state private schools. As expected, we find that the effect is larger for public than for private schools. The coefficients also again somewhat increase in magnitude as rank diminishes.

Table 5 explores potential heterogeneous effects of merit aid over time. Rather than a single merit-aid dummy, we created a set of merit aid-by-year dummy variables and estimated the model for the combined set of universities and colleges. The results are consistent with those in Table 3 in that the coefficients on the merit aid variable are smaller and statistically insignificant for the Top 15 schools, and the effect of merit aid is larger the lower the rank of the set of schools. We note that the magnitude of the coefficients increased for years around the Great Recession, as one would anticipate since we would expect students to be more sensitive to the availability of merit aid during tougher economic times.

We ran several other alternative regressions to explore the sensitivity of the results to alternative assumptions. First, the regressions in Table 3 consider all even numbered years over a relatively long time period. To explore the effects of merit aid around the year of adoption of the merit aid program, we estimate the regressions using only observations six years pre- and postmerit aid adoption in merit-aid states. These results, which are presented in Table 6, are very similar to those in Table 3, although the effects are slightly smaller in magnitude (less negative) 
in Table $6 .{ }^{18}$ The reduction using the narrow time window is consistent with estimates in Table 5 suggesting that effects were larger in magnitude during and after the Great Recession since the 6year window closes prior to 2008 for all but Tennessee.

We considered three other alternatives, and since they are consistent with the results presented in Table 3, we do not report them in the paper. We first estimated the regression equation using weak merit aid states as treatment states and excluding strong merit aid states from the analysis. As expected, the coefficients on MERIT are generally negative (with one estimate just above zero) but are smaller in magnitude than those for strong merit states and are less consistently statistically significant. Given that the merit aid programs in these states are not as generous we expected that the effects would be smaller, and perhaps hard to detect. We next added the weak merit aid states to the control states, even though this is conceptually undesirable since students in those states did receive partial treatment. The results are consistent with those in Table 3, although the magnitudes of the coefficients are moderately smaller. Finally we considered heterogeneous effects by distance. The likelihood of attending an out-of-state school may be negatively related to the distance from the home state to the out-of-state school. ${ }^{19}$ Thus, we restricted the schools in the set of ranked schools to those located within 500 miles of the population center of the state. For a few states there are no top ranked schools within 500 miles, and so these states were not included in this alternative analysis. However, the results were consistent with those reported in Table 3.

\footnotetext{
${ }^{18}$ Results not shown are very similar if we use a four-year pre- and post-merit window.

${ }^{19}$ Long (2004) finds that over time the importance of distance in selecting a college has declined, which is consistent with the findings of Hoxby (1997) regarding the changing market structure of U.S. higher education. Alm and Winters (2009) and Lowe and Viterito (1989) find that the deterrent effect of distance declines with institutional quality.
} 


\section{Summary and Conclusion}

In this paper we explore how the effects of state merit aid programs on students' decisions to attend college out-of-state differ by the "eliteness" of the out-of-state college. Using U.S. News \& World Report rankings of colleges and universities to measure "eliteness" and IPEDS data to measure freshmen enrollment by school and home state, we find that merit aid programs have a small negative, but statistically insignificant effect on out-of-state enrollment in the top ranked 15 schools. However, as the school rank falls, the negative effect on out-of-state enrollment increases in magnitude and becomes statistically significant. We also find larger average effects for public institutions than private institutions and larger effects for national universities than for national liberal arts colleges outside the top quartile. The results are not sensitive to alternative specifications.

The differing effects by the quality of institutions have implications for state merit aid programs and highlight more general differences between elite and less elite institutions. Merit aid programs were adopted in part in order to retain top students in state. Strong merit aid programs did result in a substantial percentage reduction in the number of students going to college out-of-state, including many who would have instead gone to colleges and universities ranked in the top two quartiles by USNWR. This implies that state merit aid programs can help keep many very good students in-state for college. However, our results suggest that merit aid programs did not incentivize students with the academic ability to attend top ranked national colleges and universities to attend school in state. Thus, merit aid may influence many better and brighter students to stay in-state, but it appears unlikely to influence the college choice decisions of the very best and brightest students from the state. 
The implications regarding elite enrollment are also important. Our results imply that students do not view a merit scholarship at an in-state institution as a sufficient incentive to give up attending a very top school. Thus, students appear to be very price insensitive when choosing between elite and non-elite colleges and universities. This is consistent with popular perceptions and empirical research suggesting that students receive considerable benefits from attending an elite higher education institution. 


\section{References}

Alm, James, and John V. Winters. 2009. "Distance and Intrastate College Student Migration." Economics of Education Review 28(6): 728-738.

Alter, Molly, and Randall Reback. 2014. "True for Your School? How Changing Reputations Alter Demand for Selective U.S. Colleges." Educational Evaluation and Policy Analysis 36(3): 346-370.

Avery, Christopher, Mark Glickman, Caroline M. Hoxby, and Andrew Metrick. 2013. "A Revealed Preference Ranking of U.S. Colleges and Universities." Quarterly Journal of Economics 128(1): 425-467.

Avery, Christopher, and Caroline M. Hoxby. 2004. "Do and Should Financial Aid Packages Affect Students' College Choice?” In Caroline M. Hoxby (ed), College Choices: The Economics of Where to Go, When to Go, and How to Pay for It. Chicago, IL: University of Chicago Press, pp. 239-299.

Binder, Melissa, and Philip T. Ganderton. 2004. "The New Mexico Lottery Scholarship: Does It Help Minority and Low-income Students?” In Donald E. Heller and Patricia Marin (eds.) State Merit Scholarship Programs and Racial Inequality. Cambridge, MA: Civil Rights Project at Harvard University, pp.101-22.

Bowman, Nicholas A., and Michael N. Bastedo. 2009. "Getting on the Front Page: Organizational Reputation, Status Signals, and the Impact of U.S. News and World Report on Student Decisions." Research in Higher Education 50(5): 415-436.

Brewer, Dominic J., Eric R. Eide and Ronald G. Ehrenberg. 1999. "Does It Pay to Attend an Elite Private College? Cross-Cohort Effects of College Type on Earnings," Journal of Human Resources 34 (Winter): 104-123.

Chakrabarti, Rajashri, and Joydeep Roy. 2013. "Merit Aid, Student Mobility, and the Role of College Selectivity.” FRB of New York Staff Report No. 641.

Chang, Gordon C., and J.R. Osborn. 2005. "Spectacular Colleges and Spectacular Rankings: The U.S. News Rankings of American 'Best' Colleges.” Journal of Consumer Culture 5(3): 338-364.

Clayton, Dana D. 2013. "Factors and Influences Contributing to the College Selection Decision of High Achieving High School Seniors.” Ph.D. Dissertation, Educational Leadership Doctoral Program, Western Kentucky University, Bowling Green, Kentucky. Available at http://digitalcommons.wku.edu/diss/49 
Cohodes, Sarah R., and Joshua S. Goodman. 2014. "Merit Aid, College Quality, and College Completion: Massachusetts' Adams Scholarship as an In-kind Subsidy.” American Economic Journal: Applied Economics 6(4): 251-285.

Conley, Timothy G., and Christopher R. Taber. 2011. "Inference with "Difference in Differences" with a Small Number of Policy Changes." Review of Economics and Statistics 93(1): 113-25.

Cornwell, Christopher M., David B. Mustard, and Deepa J. Sridhar. 2006. "The Enrollment Effects of Merit-based Financial Aid: Evidence from Georgia's HOPE Program.” Journal of Labor Economics 24(4): 761-86.

Curs, Bradley, and Larry D. Singell, Jr. 2002. "An Analysis of the Application and Enrollment Process for In-state and Out-of-state Students at a Large Public University." Economics of Education Review 21(2): 111-24.

Dale, Stacy B., and Alan B. Krueger. 2002. "Estimating the Payoff to Attending a More Selective College: An Application of Selection on Observables and Unobservables," Quarterly Journal of Economics 117: 1491-1527.

Bertrand, Marianne, Ester Duflo, and Sendhil Mullainathan. 2004. "How Much Should We Trust Differences-in-Differences Estimates?" Quarterly Journal of Economics 119(1), 249275.

Dynarski, Susan, 2000. "Hope for Whom? Financial Aid for the Middle Class and Its Impact on College Attendance." National Tax Journal Part 2 53(3): 629-61.

Dynarski, Susan, 2004. “The New Merit Aid.” In, College Choices: The Economics of Where to Go, When to Go, and How to Pay for It, Caroline M. Hoxby. Chicago: University of Chicago Press, pp. 63-97

Ehrenberg, Ronald G. 2004. "Econometric Studies of Higher Education." Journal of Econometrics 121(1-2): 19-37.

Ehrenberg, Ronald G. 2005. "Method or madness? Inside the U.S. News and World Report College Rankings." Journal of College Admission 189: 29-35.

Eide, Eric R., Dominic J. Brewer and Ronald G. Ehrenberg. 1998. "Does it Pay to Attend an Elite Private College: Evidence on the Effects of Undergraduate College Quality on Graduate School Attendance," Economics of Education Review 17(4): 371-376. 
Farrell, Patricia L., and Gregory S. Kienzl. 2009. “Are State Non-Need, Merit-Based Scholarship Programs Impacting College Enrollment?” Education Finance and Policy 4(2): 150-174.

Fuller, Winship C., Charles F. Manski, and David A. Wise. 1982. "New Evidence on the Economic Determinants of Postsecondary Schooling Choices." Journal of Human Resources 17(4): 476-498.

Goodman, Joshua. 2008. "Who Merits Financial Aid? Massachusetts' Adams Scholarship." Journal of Public Economics 92(10): 2121-2131.

Griffith, Amanda and Kevin Rask. 2007. "The Influence of US News and World Report Collegiate Rankings on the Matriculation Decision of High-Ability Students: 19952004." Economics of Education Review 26(2): 244-255.

Hawley, Zackary B., and Jonatan C. Rork. 2013. "The Case of State Funded Higher Education Scholarship Plans and Interstate Brain Drain." Regional Science and Urban Economics 43(2): 242-249.

Hazelkorn, Ellen. 2015. The Effects of Rankings on Student Choices and Institutional Selection. In Ben W. A. Jongbloed and Hans Vossensteyn (eds) Access and Expansion PostMassification: Opportunities and Barriers to Further Growth in Higher Education Participation. London, Routledge.

Heller, Donald E. 1997. "Student Price Response in Higher Education: An Update to Leslie and Brinkman." The Journal of Higher Education 68(6): 624-659.

Hoekstra, Mark. 2009. "The Effect of Attending the Flagship State University on Earnings: A Discontinuity-Based Approach." Review of Economics and Statistics 91(4): 717-724.

Hoxby, Caroline M. 1997. "How the Changing Market Structure of U.S. Higher Education Explains College Tuition.” NBER Working Paper 6323. Cambridge, MA: National Bureau of Economic Research.

Hoxby Caroline M. 1998. "The Return to Attending a More Selective College: 1960 to the Present." Harvard Economics Department Working Paper.

Hoxby Caroline M., and Bridget Terry Long. 1999. "Explaining Rising Income and Wage Inequality Among the College Educated", NBER Working Paper 6873. Cambridge, MA: National Bureau of Economic Research.

Hurwitz, Michael. 2012. "The Impact of Institutional Grant Aid on College Choice." Educational Evaluation and Policy Analysis 34(3): 344-363. 
Jacob, Brian, Brian McCall, and Kevin M. Stange. 2013. "College as Country Club: Do Colleges Cater to Students' Preferences for Consumption?” NBER Working Paper 18745. Cambridge, MA: National Bureau of Economic Research.

Kohn, Meir G., Charles Manski, and David Mundel. 1976. "An Empirical Investigation of Factors Influencing College-Going Behavior. Annals of Economic and Social Measurement 5(4): 391-419.

Long, Bridget Terry. 2004. "How Have College Decisions Changed Over Time? An Application of the Conditional Logistic Choice Model." Journal of Econometrics 121: 271-296.

Long, Bridget Terry. 2007. "The Contributions of Economics to the Study of College Access and Success." The Teachers College Record 109(10): 2367-2443.

Long, Mark C. 2008. "College Quality and Early Adult Outcomes." Economics of Education Review 27(5): 588-602.

Long, Mark C. 2010. "Changes in the Returns to Education and College Quality." Economics of Education Review 29(3): 338-347.

Lowe, John C., and Arthur Viterito. 1989. "Differential Spatial Attraction of Private Colleges and Universities in the United States." Economic Geography 65(3): 208-215.

Machung, Anne. 1998. "Playing the Rankings Game.” Change July/August: 12-16.

Manski, Charles F., and David A. Wise. 1983. College Choice in America. Cambridge, MA: Harvard University Press.

McDonough, Patricia M., Anthony Lising Antonio, MaryBeth Walpole, and Leonor Xóchitl Pérez. 1998. "College Rankings: Democratized College Knowledge for Whom?" Research in Higher Education 39(5): 513-537.

McDuff, DeForest. 2007. "Quality, Tuition, and Applications to In-state Public Colleges." Economics of Education Review 26(4): 433-449.

Meredith, Marc. 2004. "Why Do Universities Compete in the Ratings Game? An Empirical Analysis of the Effects of the U.S. News and World Report College Rankings." Research in Higher Education 45(5): 443-461.

Monks, James, and Ronald G. Ehrenberg. 1999. "The Impact of US News and World Report College Rankings on Admission Outcomes and Pricing Decisions at Selective Private Institutions.” NBER Working Paper 7227. Cambridge, MA: National Bureau of Economic Research. 
Morse, Bob. 2012. “Emory University Misreported Admissions Data.” U.S. News \& World Report, blog of August 17, 2012, available at http://www.usnews.com/education/blogs/college-rankings-blog/2012/08/17/emoryuniversity-misreported-admissions-data. Accessed August 8, 2015.

Nurnberg, Peter, Morton Schapiro, and David Zimmerman. 2012. "Students Choosing Colleges: Understanding the Matriculation Decision at a Highly Selective Private Institution." Economics of Education Review 31(1): 1-8.

Orsuwan, Meechai, and Ronald H. Heck. 2009. "Merit-based Student Aid and Freshman Interstate College Migration: Testing a Dynamic Model of Policy Change." Research in Higher Education 50(1): 24-51.

Ren, Siyuan. 2013. "The Impact of U.S. News \& World Report College Rankings: An Update to Monks and Ehrenberg." M.A. Thesis, College of Education, Pennsylvania State University.

Rizzo, Michael J., and Ronald E. Ehrenberg. 2004. "Resident and Nonresident Tuition and Enrollment at Flagship State Universities." In Caroline Hoxby (Ed.), College Choices: The Economics of Where to Go, When to Go, and How to Pay for It (pp. 303-349). Chicago: University of Chicago Press.

Sjoquist, David L., and John V. Winters. 2013. "The Effects of HOPE on Post-College Retention in the Georgia Workforce." Regional Science and Urban Economics 43(3): 479-490.

Sjoquist, David L., and John V. Winters. 2014. "Merit Aid and Post-College Retention in the State." Journal of Urban Economics 80: 39-50.

Sjoquist, David L., and John V. Winters. 2015. "State Merit-based Financial Aid Programs and College Attainment.” Journal of Regional Science 55(3): 364-390.

Webster, Thomas J. 2001. "A Principal Component Analysis of the U.S. News \& World Report Tier Rankings of Colleges and Universities." Economics of Education Review 20(3): 235244.

Weiler, William C. 1996. "Factors Influencing the Matriculation Choices of High Ability Students." Economics of Education Review 15(1): 23-36.

Winters, John V. 2012. "Cohort Crowding and Nonresident College Enrollment." Economics of Education Review 31(3): 30-40.

Zhang, Liang, and Erik C. Ness. 2010. "Does State Merit-based Aid Stem Brain Drain?" Educational Evaluation and Policy Analysis 32(2): 143-165. 
Table 1: States with Strong Merit Aid Programs

\begin{tabular}{lll}
\hline State & Year Enacted & Program Name \\
\hline Florida & 1997 & Florida Bright Futures Scholarship \\
Georgia & 1993 & Georgia HOPE Scholarship \\
Kentucky & 1999 & Kentucky Educational Excellence Scholarship \\
Louisiana & 1998 & Louisiana TOPS Scholarship \\
Nevada & 2000 & Nevada Millennium Scholarship \\
New Mexico & 1997 & New Mexico Lottery Success Scholarship \\
South Carolina & 1998 & South Carolina LIFE Scholarship and HOPE Scholarship \\
Tennessee & 2003 & Tennessee HOPE Scholarship \\
West Virginia & 2002 & West Virginia PROMISE Scholarship \\
\hline
\end{tabular}

Sources: Sjoquist and Winters (2014, 2015). 
Table 2: Summary Statistics

\begin{tabular}{|c|c|c|c|c|}
\hline & \multicolumn{2}{|c|}{$\underline{\text { Strong Merit States }}$} & \multicolumn{2}{|c|}{ Non-Merit States } \\
\hline & Mean & Std. Dev. & Mean & Std. Dev. \\
\hline \multicolumn{5}{|l|}{ Log Recent FTF Out-of-State Enrollment Measures } \\
\hline Top 15 - Universities and Colleges & 4.945 & 0.868 & 5.389 & 0.848 \\
\hline Top 15 - National Universities & 4.557 & 0.918 & 4.978 & 0.905 \\
\hline Top 15 - National LACs & 3.751 & 0.828 & 4.243 & 0.797 \\
\hline 16-25 - Universities and Colleges & 4.479 & 0.840 & 4.951 & 0.809 \\
\hline 16-25 - National Universities & 4.302 & 0.881 & 4.514 & 0.925 \\
\hline 16-25 - National LACs & 2.467 & 0.941 & 3.639 & 0.989 \\
\hline Other Top Quartile - Universities and Colleges & 5.350 & 0.778 & 5.666 & 0.894 \\
\hline Other Top Quartile - National Universities & 5.269 & 0.802 & 5.496 & 0.912 \\
\hline Other Top Quartile - National LACs & 2.556 & 0.883 & 3.514 & 1.108 \\
\hline Second Quartile - Universities and Colleges & 5.817 & 0.750 & 6.381 & 0.765 \\
\hline Second Quartile - National Universities & 5.567 & 0.731 & 6.107 & 0.858 \\
\hline Second Quartile - National LACs & 4.228 & 0.968 & 4.809 & 0.667 \\
\hline Third Quartile - Universities and Colleges & 5.992 & 0.875 & 6.230 & 0.742 \\
\hline Third Quartile - National Universities & 5.837 & 0.959 & 6.039 & 0.778 \\
\hline Third Quartile - National LACs & 3.783 & 0.638 & 4.341 & 0.756 \\
\hline Fourth Quartile - Universities and Colleges & 4.660 & 0.752 & 5.432 & 1.029 \\
\hline Fourth Quartile - National Universities & 4.373 & 0.816 & 5.028 & 1.164 \\
\hline Fourth Quartile - National LACs & 2.962 & 0.960 & 4.134 & 0.906 \\
\hline \multicolumn{5}{|l|}{ State Control Variables } \\
\hline$\overline{\text { Log population age } 18}$ & 10.945 & 0.700 & 10.864 & 0.902 \\
\hline Unemployment rate & 6.484 & 2.116 & 5.274 & 1.797 \\
\hline Log median household income & 10.405 & 0.282 & 10.570 & 0.300 \\
\hline Log in-state tuition at public flagships & 8.065 & 0.601 & 8.407 & 0.643 \\
\hline Observations & \multicolumn{2}{|c|}{117} & \multicolumn{2}{|c|}{247} \\
\hline
\end{tabular}

Notes: The 13 years of data are for even years 1986-2012 excluding 1990.

The 1988 flow for West Virginia to LACs ranked 16-25 was zero; the missing log value was recoded to equal -1 . All other flows considered were greater than zero. 
Table 3: Effects of Strong Merit Aid on Log Recent FTF Enrollment Out-Migration by Type of Institution

\begin{tabular}{|c|c|c|c|c|c|c|}
\hline Institution Type: & $\begin{array}{c}(1) \\
\text { Top } \\
15 \\
\end{array}$ & $\begin{array}{c}(2) \\
\text { Ranks } \\
16-25 \\
\end{array}$ & $\begin{array}{c}\text { (3) } \\
\text { Other Top } \\
\text { Quartile }\end{array}$ & $\begin{array}{c}\text { (4) } \\
\text { Second } \\
\text { Quartile }\end{array}$ & $\begin{array}{c}\text { (5) } \\
\text { Third } \\
\text { Quartile }\end{array}$ & $\begin{array}{c}\text { (6) } \\
\text { Fourth } \\
\text { Quartile }\end{array}$ \\
\hline \multicolumn{7}{|l|}{ A. Universities and Colleges } \\
\hline Strong Merit & $\begin{array}{l}-0.027 \\
(0.037)\end{array}$ & $\begin{array}{c}-0.239 \\
(0.063)^{* * *}\end{array}$ & $\begin{array}{c}-0.212 \\
(0.089)^{* *}\end{array}$ & $\begin{array}{c}-0.239 \\
(0.064)^{* * *}\end{array}$ & $\begin{array}{c}-0.346 \\
(0.061)^{* * *}\end{array}$ & $\begin{array}{c}-0.327 \\
(0.064) * * *\end{array}$ \\
\hline \multicolumn{7}{|l|}{ B. National Universities } \\
\hline Strong Merit & $\begin{array}{l}-0.016 \\
(0.034)\end{array}$ & $\begin{array}{c}-0.240 \\
(0.071)^{* * *}\end{array}$ & $\begin{array}{c}-0.212 \\
(0.093) * *\end{array}$ & $\begin{array}{c}-0.268 \\
(0.072)^{* * *}\end{array}$ & $\begin{array}{c}-0.368 \\
(0.065)^{* * *}\end{array}$ & $\begin{array}{c}-0.369 \\
(0.076) * * *\end{array}$ \\
\hline \multicolumn{7}{|l|}{ C. National LACs } \\
\hline Strong Merit & $\begin{array}{l}-0.029 \\
(0.042) \\
\end{array}$ & $\begin{array}{c}-0.184 \\
(0.081)^{* *}\end{array}$ & $\begin{array}{c}-0.332 \\
(0.076)^{* * *}\end{array}$ & $\begin{array}{c}-0.137 \\
(0.072)^{*}\end{array}$ & $\begin{array}{c}-0.202 \\
(0.113)^{*}\end{array}$ & $\begin{array}{l}-0.167 \\
(0.109)\end{array}$ \\
\hline
\end{tabular}

Note: Standard errors in parentheses are clustered by state of origin. Weak merit states are excluded from the control group. All regressions include 364 state-year observations. All regressions include state fixed effects, year fixed effects, region-byyear fixed effects, and state control variables.

*Significant at $10 \%$ level based on clustered standard errors; **Significant at $5 \%$ level; ***Significant at $1 \%$ level. 
Table 4: Effects of Strong Merit Aid on Enrollment - Separately for Public and Private Institutions

\begin{tabular}{lcccc}
\hline & $(1)$ & $(2)$ & $(3)$ & $(4)$ \\
Institution Type: & $\begin{array}{c}\text { First } \\
\text { Quartile }\end{array}$ & $\begin{array}{c}\text { Second } \\
\text { Quartile }\end{array}$ & $\begin{array}{c}\text { Third } \\
\text { Quartile }\end{array}$ & $\begin{array}{c}\text { Fourth } \\
\text { Quartile }\end{array}$ \\
\hline A. Public Universities and Colleges & & & & \\
Strong Merit & -0.270 & -0.264 & -0.404 & -0.325 \\
& $(0.101)^{* *}$ & $(0.085)^{* * *}$ & $(0.076)^{* * *}$ & $(0.080)^{* * *}$ \\
B. Private Universities and Colleges & & & & \\
Strong Merit & -0.085 & -0.189 & -0.131 & -0.232 \\
& $(0.043)^{*}$ & $(0.038)^{* * *}$ & $(0.068)^{*}$ & $(0.071)^{* * *}$ \\
\hline
\end{tabular}

Note: Standard errors in parentheses are clustered by state of origin. Weak merit states are excluded from the control group. All regressions include state fixed effects, year fixed effects, region-by-year fixed effects, and state control variables.

*Significant at $10 \%$ level based on clustered standard errors; **Significant at $5 \%$ level; *** Significant at $1 \%$ level. 
Table 5: Effects of Strong Merit Aid on Log Recent FTF Enrollment Out-Migration by Year

\begin{tabular}{|c|c|c|c|c|c|c|}
\hline Institution Type: & $\begin{array}{c}(1) \\
\text { Top } \\
15\end{array}$ & $\begin{array}{c}(2) \\
\text { Ranks } \\
16-25 \\
\end{array}$ & $\begin{array}{c}\text { (3) } \\
\text { Other Top } \\
\text { Quartile }\end{array}$ & $\begin{array}{c}(4) \\
\text { Second } \\
\text { Quartile }\end{array}$ & $\begin{array}{c}(5) \\
\text { Third } \\
\text { Quartile }\end{array}$ & $\begin{array}{c}\text { (6) } \\
\text { Fourth } \\
\text { Quartile }\end{array}$ \\
\hline \multicolumn{7}{|l|}{ Universities and Colleges } \\
\hline Strong Merit*Year1994 & $\begin{array}{c}0.041 \\
(0.041)\end{array}$ & $\begin{array}{l}-0.011 \\
(0.054)\end{array}$ & $\begin{array}{c}0.033 \\
(0.058)\end{array}$ & $\begin{array}{c}-0.153 \\
(0.049)^{* * *}\end{array}$ & $\begin{array}{c}-0.202 \\
(0.057)^{* * *}\end{array}$ & $\begin{array}{l}-0.144 \\
(0.107)\end{array}$ \\
\hline Strong Merit*Year1996 & $\begin{array}{c}0.030 \\
(0.047)\end{array}$ & $\begin{array}{c}-0.233 \\
(0.083)^{* * *}\end{array}$ & $\begin{array}{l}-0.066 \\
(0.074)\end{array}$ & $\begin{array}{c}-0.220 \\
(0.052)^{* * *}\end{array}$ & $\begin{array}{c}-0.425 \\
(0.069)^{* * *}\end{array}$ & $\begin{array}{c}-0.374 \\
(0.119)^{* * *}\end{array}$ \\
\hline Strong Merit*Year1998 & $\begin{array}{c}0.053 \\
(0.055)\end{array}$ & $\begin{array}{c}-0.139 \\
(0.079)^{*}\end{array}$ & $\begin{array}{l}-0.037 \\
(0.100)\end{array}$ & $\begin{array}{l}-0.060 \\
(0.083)\end{array}$ & $\begin{array}{c}-0.170 \\
(0.081)^{* *}\end{array}$ & $\begin{array}{l}-0.084 \\
(0.134)\end{array}$ \\
\hline Strong Merit*Year 2000 & $\begin{array}{l}-0.028 \\
(0.071)\end{array}$ & $\begin{array}{c}-0.191 \\
(0.082)^{* *}\end{array}$ & $\begin{array}{c}-0.163 \\
(0.095)^{*}\end{array}$ & $\begin{array}{c}-0.250 \\
(0.083)^{* * *}\end{array}$ & $\begin{array}{c}-0.223 \\
(0.098) * *\end{array}$ & $\begin{array}{c}-0.293 \\
(0.125)^{* *}\end{array}$ \\
\hline Strong Merit*Year2002 & $\begin{array}{l}-0.042 \\
(0.057)\end{array}$ & $\begin{array}{c}-0.251 \\
(0.084)^{* * *}\end{array}$ & $\begin{array}{c}-0.197 \\
(0.082) * *\end{array}$ & $\begin{array}{c}-0.232 \\
(0.088)^{* *}\end{array}$ & $\begin{array}{c}-0.338 \\
(0.100)^{* * *}\end{array}$ & $\begin{array}{c}-0.307 \\
(0.138) * *\end{array}$ \\
\hline Strong Merit*Year2004 & $\begin{array}{l}-0.044 \\
(0.059)\end{array}$ & $\begin{array}{l}-0.177 \\
(0.105)\end{array}$ & $\begin{array}{c}-0.202 \\
(0.083)^{* *}\end{array}$ & $\begin{array}{c}-0.235 \\
(0.081)^{* * *}\end{array}$ & $\begin{array}{c}-0.412 \\
(0.098)^{* * *}\end{array}$ & $\begin{array}{c}-0.495 \\
(0.245)^{*}\end{array}$ \\
\hline Strong Merit*Year2006 & $\begin{array}{c}0.025 \\
(0.066)\end{array}$ & $\begin{array}{c}-0.269 \\
(0.100)^{* *}\end{array}$ & $\begin{array}{c}-0.257 \\
(0.112)^{* *}\end{array}$ & $\begin{array}{c}-0.235 \\
(0.070)^{* * *}\end{array}$ & $\begin{array}{c}-0.276 \\
(0.086)^{* * *}\end{array}$ & $\begin{array}{c}-0.393 \\
(0.113)^{* * *}\end{array}$ \\
\hline Strong Merit*Year2008 & $\begin{array}{l}-0.087 \\
(0.053)\end{array}$ & $\begin{array}{c}-0.270 \\
(0.110)^{* *}\end{array}$ & $\begin{array}{c}-0.387 \\
(0.139)^{* * *}\end{array}$ & $\begin{array}{c}-0.352 \\
(0.104)^{* * *}\end{array}$ & $\begin{array}{c}-0.437 \\
(0.097) * * *\end{array}$ & $\begin{array}{c}-0.376 \\
(0.103)^{* * *}\end{array}$ \\
\hline Strong Merit*Year2010 & $\begin{array}{l}-0.116 \\
(0.096)\end{array}$ & $\begin{array}{c}-0.455 \\
(0.112)^{* * *}\end{array}$ & $\begin{array}{c}-0.373 \\
(0.147)^{* *}\end{array}$ & $\begin{array}{c}-0.353 \\
(0.112)^{* * *}\end{array}$ & $\begin{array}{c}-0.474 \\
(0.089) * * *\end{array}$ & $\begin{array}{c}-0.365 \\
(0.118)^{* * *}\end{array}$ \\
\hline Strong Merit*Year2012 & $\begin{array}{l}-0.035 \\
(0.111)\end{array}$ & $\begin{array}{c}-0.260 \\
(0.098) * *\end{array}$ & $\begin{array}{l}-0.259 \\
(0.158)\end{array}$ & $\begin{array}{c}-0.263 \\
(0.126)^{* *}\end{array}$ & $\begin{array}{c}-0.521 \\
(0.113) * * *\end{array}$ & $\begin{array}{c}-0.413 \\
(0.129)^{* * *}\end{array}$ \\
\hline
\end{tabular}


Table 6: Effects of Strong Merit Aid - Restricted to 6 Years Before and After Adoption in Merit States

\begin{tabular}{|c|c|c|c|c|c|c|}
\hline & (1) & (2) & (3) & (4) & (5) & (6) \\
\hline Institution Type: & $\begin{array}{c}\text { Top } \\
15 \\
\end{array}$ & $\begin{array}{l}\text { Ranks } \\
16-25 \\
\end{array}$ & $\begin{array}{c}\text { Other Top } \\
\text { Quartile }\end{array}$ & $\begin{array}{c}\text { Second } \\
\text { Quartile }\end{array}$ & $\begin{array}{c}\text { Third } \\
\text { Quartile }\end{array}$ & $\begin{array}{c}\text { Fourth } \\
\text { Quartile }\end{array}$ \\
\hline \multicolumn{7}{|c|}{ A. Universities and Colleges } \\
\hline Strong Merit & $\begin{array}{c}0.004 \\
(0.026)\end{array}$ & $\begin{array}{c}-0.146 \\
(0.054) * *\end{array}$ & $\begin{array}{c}-0.128 \\
(0.059)^{*}\end{array}$ & $\begin{array}{c}-0.167 \\
(0.043)^{* * *}\end{array}$ & $\begin{array}{c}-0.263 \\
(0.045)^{* * *}\end{array}$ & $\begin{array}{c}-0.298 \\
(0.064)^{* * *}\end{array}$ \\
\hline \multicolumn{7}{|c|}{ B. National Universities } \\
\hline Strong Merit & $\begin{array}{c}0.032 \\
(0.024)\end{array}$ & $\begin{array}{c}-0.144 \\
(0.059) * *\end{array}$ & $\begin{array}{c}-0.119 \\
(0.062)^{*}\end{array}$ & $\begin{array}{c}-0.212 \\
(0.050)^{* * *}\end{array}$ & $\begin{array}{c}-0.272 \\
(0.047)^{* * *}\end{array}$ & $\begin{array}{c}-0.359 \\
(0.091)^{* * *}\end{array}$ \\
\hline \multicolumn{7}{|l|}{ C. National LACs } \\
\hline Strong Merit & $\begin{array}{l}-0.033 \\
(0.046)\end{array}$ & $\begin{array}{l}-0.141 \\
(0.098)\end{array}$ & $\begin{array}{c}-0.360 \\
(0.085)^{* * *}\end{array}$ & $\begin{array}{l}-0.018 \\
(0.048)\end{array}$ & $\begin{array}{c}-0.164 \\
(0.089)^{*}\end{array}$ & $\begin{array}{l}-0.055 \\
(0.101)\end{array}$ \\
\hline
\end{tabular}

Note: Standard errors in parentheses are clustered by state of origin. Weak merit states are excluded from the control group. All regressions include state fixed effects, year fixed effects, region-by-year fixed effects, and state control variables.

*Significant at $10 \%$ level based on clustered standard errors; **Significant at 5\% level; ***Significant at $1 \%$ level. 


\begin{tabular}{|c|c|c|c|}
\hline Nation Universities & Rank Category & National Liberal Arts Colleges & Rank Category \\
\hline Brown University & Top 15 & Amherst College & Top 15 \\
\hline California Institute of Technology & Top 15 & Bowdoin College & Top 15 \\
\hline Columbia University & Top 15 & Carleton College & Top 15 \\
\hline Cornell University & Top 15 & Claremont McKenna College & Top 15 \\
\hline Dartmouth College & Top 15 & Davidson College & Top 15 \\
\hline Duke University & Top 15 & Middlebury College & Top 15 \\
\hline Harvard University & Top 15 & Oberlin College & Top 15 \\
\hline Johns Hopkins University & Top 15 & Pomona College & Top 15 \\
\hline Massachusetts Institute of Technology & Top 15 & Smith College & Top 15 \\
\hline Princeton University & Top 15 & Swarthmore College & Top 15 \\
\hline Stanford University & Top 15 & Vassar College & Top 15 \\
\hline University of California-Berkeley & Top 15 & Washington and Lee University & Top 15 \\
\hline University of Chicago & Top 15 & Wellesley College & Top 15 \\
\hline University of Pennsylvania & Top 15 & Wesleyan College (CT) & Top 15 \\
\hline Yale University & Top 15 & Williams College & Top 15 \\
\hline Carnegie Mellon University & $16-25$ & Barnard College & $16-25$ \\
\hline Georgetown University & $16-25$ & Bates College & $16-25$ \\
\hline Northwestern University & $16-25$ & Bryn Mawr College & $16-25$ \\
\hline Rice University & $16-25$ & Colby College & $16-25$ \\
\hline University of California-Los Angeles & $16-25$ & Colgate University & $16-25$ \\
\hline University of Michigan-Ann Arbor & $16-25$ & Grinnell College & $16-25$ \\
\hline University of North Carolina-Chapel Hill & $16-25$ & Hamilton College & $16-25$ \\
\hline University of Rochester & $16-25$ & Haverford College & $16-25$ \\
\hline University of Virginia & $16-25$ & Mount Holyoke College & $16-25$ \\
\hline Washington University in St. Louis & $16-25$ & Occidental College & $16-25$ \\
\hline Brandeis University & Other top quart. & Bucknell University & Other top quart. \\
\hline Case Western Reserve University & Other top quart. & College of the Holy Cross & Other top quart. \\
\hline College of William and Mary & Other top quart. & Colorado College & Other top quart. \\
\hline Emory University & Other top quart. & Dickinson College & Other top quart. \\
\hline Georgia Institute of Technology & Other top quart. & Franklin and Marshall College & Other top quart. \\
\hline Lehigh University & Other top quart. & Gettysburg College & Other top quart. \\
\hline New York University & Other top quart. & Kenyon College & Other top quart. \\
\hline Pennsylvania State University & Other top quart. & Lafayette College & Other top quart. \\
\hline Purdue University-West Lafayette & Other top quart. & Scripps College & Other top quart. \\
\hline Rensselaer Polytechnic Institute & Other top quart. & Trinity College & Other top quart. \\
\hline Rutgers University-New Brunswick & Other top quart. & Union College & Other top quart. \\
\hline Tufts University & Other top quart. & & \\
\hline Tulane University & Other top quart. & & \\
\hline University of California-Davis & Other top quart. & & \\
\hline University of California-Irvine & Other top quart. & & \\
\hline University of California-San Diego & Other top quart. & & \\
\hline University of Connecticut-Storrs & Other top quart. & & \\
\hline University of Georgia & Other top quart. & & \\
\hline University of Illinois Urbana-Champaign & Other top quart. & & \\
\hline University of Miami & Other top quart. & & \\
\hline University of Notre Dame & Other top quart. & & \\
\hline University of Southern California & Other top quart. & & \\
\hline University of Washington & Other top quart. & & \\
\hline University of Wisconsin-Madison & Other top quart. & & \\
\hline Vanderbilt University & Other top quart. & & \\
\hline Virginia Tech & Other top quart. & & \\
\hline
\end{tabular}

